\title{
PENGEMBANGAN PROTOTIPE STASIUN OBSERVASI \\ MARITIM NEAR REAL TIME DI KAWASAN RENCANA \\ NATIONAL SCIENCE TECHNOPARK MARITIME, PENAJAM PASER UTARA
}

\section{PROTOTYPE DEVELOPMENT OF NEAR REAL TIME MARITIME OBSERVATION STATION AT PROPOSED NATIONAL SCIENCE TECHNOPARK MARITIME REGION, PENAJAM PASER UTARA}

\author{
Endro Soeyanto*, Agus Sudaryanto, dan Rizki Adi Nugroho \\ Balai Teknologi Survei Kelautan, Badan Pengkajian dan Penerapan Teknologi (BPPT), \\ Jl. MH. Thamrin No. 8, Jakarta \\ *E-mail: endro.soeyanto@bpt.go.id
}

\begin{abstract}
ABSTRAK
Upaya pemantauan lingkungan termasuk kondisi oseanografi dan interaksinya dengan atmosfer adalah penting untuk memberikan data dan informasi bagi pemanfaatan, perlindungan dan pengelolaan lingkungan maritim. Pemenuhan sistem pemantauan yang terus-menerus dan mendekati real-time menjadi suatu kebutuhan. Kabupaten Penajam Paser Utara (Kab. PPU) telah ditetapkan sebagai lokasi Pembangunan Pusat Riset dan Inovasi Teknologi Kelautan atau National Science Technology Park - Maritime (NSTP-M) yang dilengkapi infrastruktur stasiun pemantauan maritim. Dengan menggabungkan berbagai subsistem, termasuk akuisisi data, pendistribusian data dan pengelolaan catu daya, penelitian ini bertujuan untuk memberikan gambaran tentang pengembangan sistem pemantauan dan data yang dihasilkan dari stasiun pengamatan maritim tersebut. Sebagai hasilnya, stasiun pengamatan maritim tersebut telah dapat memantau parameter-parameter cuaca, pasang surut dan arus permukaan secara kontinu dan near Real- Time (nRT) dengan mengadopsi survei Meteorologi-Oseanografi (Met-Ocean) yang terintegrasi di Read Down Station (RDS), sebagai pusat pengolahan dan pengelolaan data di BPPT.
\end{abstract}

Kata Kunci: Stasiun Observasi Maritim, survei oseanografi - meteorologi, NSTP Maritim, Kab. Penajam Paser Utara

\section{ABSTRACT}

[Prototype Development of Near Real Time Maritime Observation Station at Regional of Proposed National Science Technopark Maritime, Penajam Paser Utara] Environmental monitoring efforts including oceanographic conditions and their interactions with the atmosphere are important in efforts to provide data and information for the use, protection and management of the maritime environment. Fulfillment of a continuous and near real-time monitoring system becomes a necessity. Penajam Paser Utara Region has been designated as the location of National Science Technology Park - Maritime (NSTP-M) development which facilitated by a maritime observation station infrastructure. By combining various subsystems, including data acquisition, data distribution and power supply management, this study aims to provide an overview of the development of monitoring system and the data generated from the maritime observation stations. As the result, the maritime observation station has been able to monitor weather parameters, tides and surface currents continuously and near real time (nRT) by adopting the Meteorological-Oceanographic (Met-Ocean) survey which is integrated in the Read Down Station (RDS) as data processing and management center in $B P P T$.

Keywords: Maritime Observation Station, Meteorology-Oceanography Survey, NSTP Maritime, District of Penajam Paser Utara 


\section{PENDAHULUAN}

Letak strategis dan peranan penting perairan Indonesia, khususnya Perairan Kalimantan Timur membutuhkan pemanfaatan, perlindungan, dan pengelolaan kawasan perairan yang berwawasan dan berkesinambungan. Undang-Undang Nomor 32 tahun 2009 tentang Perlindungan dan Pengelolaan Lingkungan Hidup mengamanatkan kepada pemerintah dan masyarakat untuk mencegah terjadinya pencemaran dan/atau kerusakan lingkungan hidup. Karena itu upaya pemantauan lingkungan termasuk parameter meteorologis dan oseanografis perairan untuk kesinambungan pembangunan adalah bagian penting dalam perencanaan, pemanfaatan dan pengendalian lingkungan hidup.

Provinsi Kalimantan Timur yang berbatasan pada sisi Timur dengan Selat Makassar, merupakan wilayah yang mempunyai potensi kemaritiman yang besar dengan berbagai sumberdaya kelautan dan perikanannya (Simreg-Bappenas, 2020; KKP, 2018). Di wilayah ini, khususnya di Kabupaten Penajam Paser Utara (Kab. PPU) telah ditetapkan sebagai salah satu lokasi untuk Pembangunan Kawasan Pusat Riset dan Inovasi Teknologi Kelautan atau yang lebih dikenal sebagai National Science Technology Park-Maritime atau NSTP-M (Balai Teknologi Survei Kelautan, 2015; Soeyanto dan Arifiyana, 2018; Ardhyastuti, 2019). Berbagai fasilitas akan dibangun sebagai bagian dari NSTP-M salah satunya adalah stasiun pengamatan maritim yang merupakan salah satu fasilitas pendukung dalam pemantauan kondisi perairan di kawasan tersebut. Selain sebagai upaya untuk memantau dinamika perairan dan atmosfer yang dapat dimanfaatkan untuk perlindungan dan pengelolaan lingkungan, stasiun observasi maritim NSTP-M juga merupakan prototipe yang dikembangkan untuk memantau data dan informasi dari jarak jauh secara cepat, kotinu dan near realtime. Di Amerika Serikat, sistem pemantauan data dan informasi oseanografi secara near real-time ini disebut Physical Oceanographic Real-Time System (PORTS) yang dikembangkan oleh NOAA (Edwing, 2019). Di Indonesia, sistem pemantauan near real-time lebih banyak dikembangkan di perairan darat (Wahyono, 2018), sedangkan untuk wilayah pantai belum banyak dilakukan. Tulisan ini bertujuan untuk memberikan gambaran tentang sistem pemantauan yang dikembangkan dan data yang dihasilkan dari pengembangan stasiun pengamatan maritim untuk NSTP-M di Kab. PPU (NSTP-M PPU), Kalimantan Timur.

\section{METODOLOGI}

\subsection{Lokasi dan Waktu}

Lokasi penempatan stasiun pengamatan maritim untuk rencana NSTP-M PPU dilaksanakan di lokasi Pelabuhan Penyeberangan PT. Angkutan Sungai Danau dan Penyeberangan Indonesia Ferry (PT. ASDP Indonesia Ferry), Kab. PPU, Kalimantan Timur (Gambar 1). Kegiatan penelitian dan pengembangan ini dilaksanakan selama tahun anggaran 2015-2016 melalui Program Maritime Technopark, Badan Pengkajian dan Penerapan Teknologi (BPPT). 


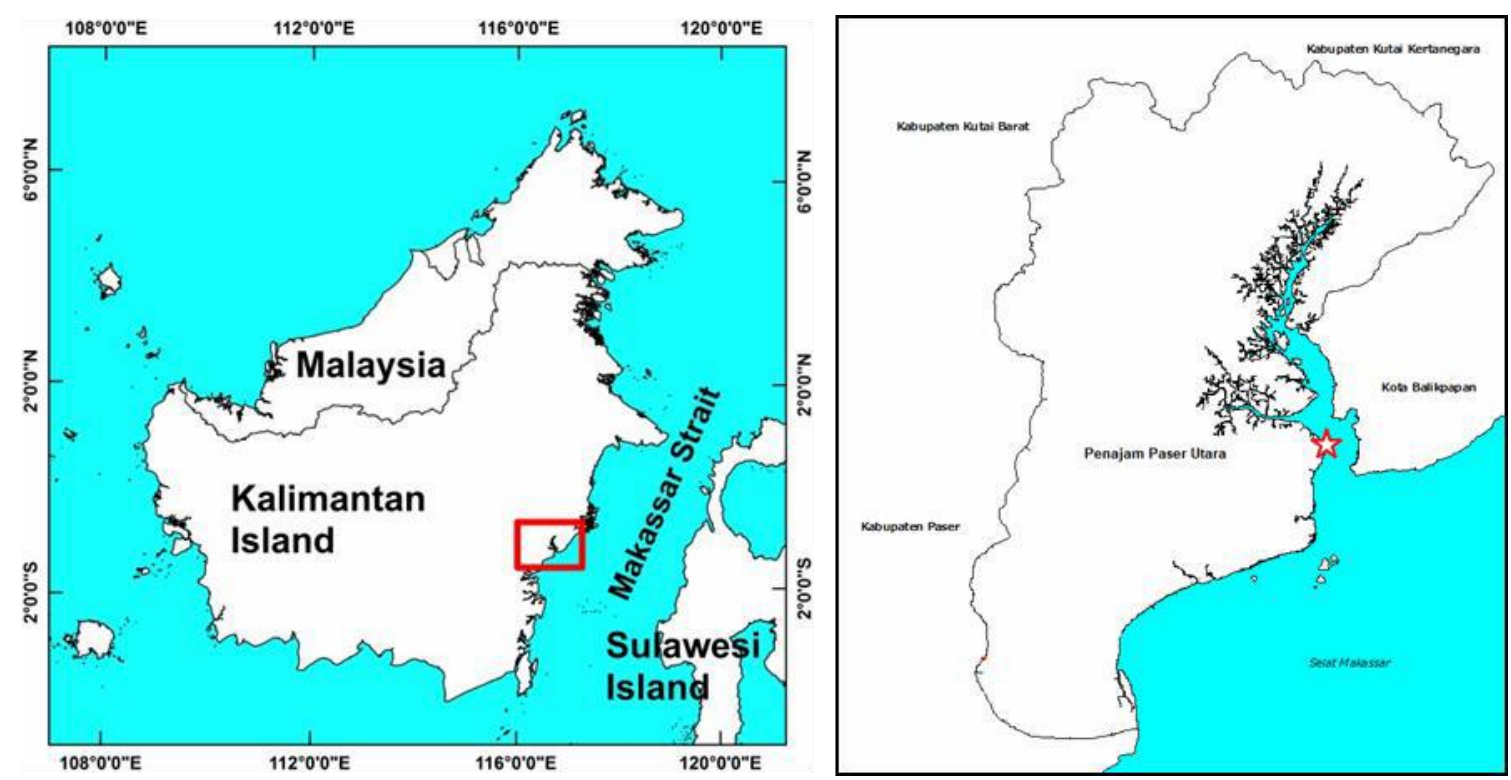

Gambar 1. Peta Kalimantan yang menunjukkan lokasi penempatan prototipe stasiun pemanatauan maritim (bintang merah = lokasi pelabuhan penyeberangan PT. ASDP Indonesia Ferry Kab. PPU) pada Kawasan NSTP-M PPU.

\subsection{Bahan dan Metode}

Sistem yang akan dibangun mengacu pada sistem PORTS milik NOAA (Gambar 2), yaitu suatu sistem untuk mengintegrasikan pengamatan lingkungan secara real-time, yang dapat digunakan untuk berbagai pemanfaatan yaitu mengukur dan menyebarluaskan pengamatan, prediksi, dan siaran / prakiraan cuaca untuk ketinggian air, arus laut, salinitas dan parameter meteorologi misalnya, angin, gelombang, tekanan atmosfer, jarak pandang, suhu udara dan air (Edwing, 2019). Dalam stasiun pengamatan maritim di Kawasan NSTP-M PPU, akan digabungkan berbagai subsistem meliputi subsistem akuisisi data, pendistribusian data dan pengelolaan catu daya (kelistrikan). Akuisisi data menggunakan peralatan Automated Weather Station (AWS) Tipe MetPak RG (+ Rain Gauge) merek Gill Instruments untuk memantau parameter meteorologi, dan peralatan Side-Looking ADCP Argonaut Tipe SL-500 merek SONTEK untuk memantau parameter oseanografi. Untuk pendistribusian data menggunakan Tipe SPF1500 Merk SONTEK dan Kabel datasepanjang 200 meter. Sedangkan manajemen catu daya (kelistrikan) menggunakan beberapa komponen seperti Pengatur Daya (Solar Panel dan Baterei Kering) dan Regulator (BCR Controller, PCB Power, Inverter, Panel display dan komponen proteksi tambahan, seperti kipas pendingin, saklar, Magnetic Circuit Breaker ( MCB). 


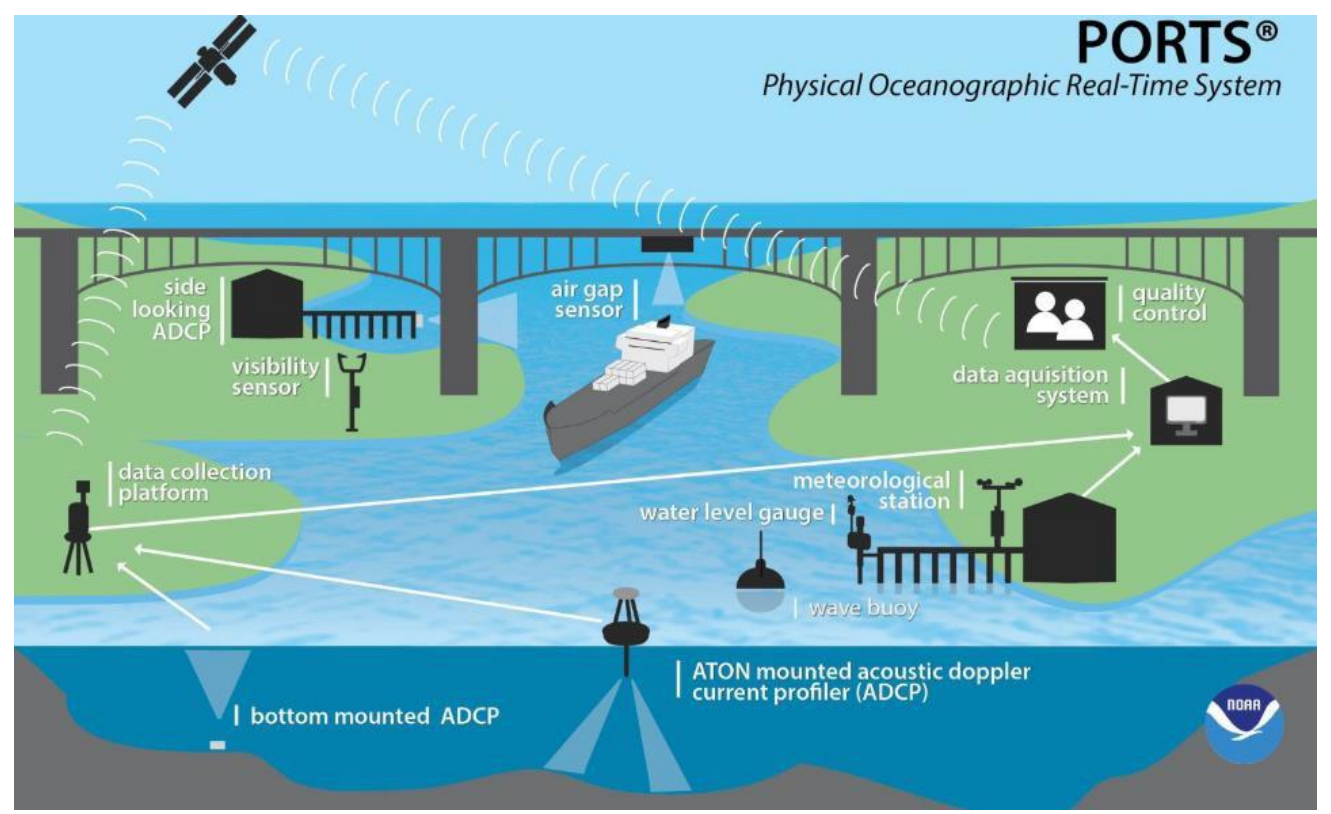

Gambar 2. Sistem pemantauan lingkungan perairan PORTS milik NOAA, Amerika Serikat (https://tidesandcurrents.noaa.gov/ports.html)

\section{HASIL DAN PEMBAHASAN}

\section{Sistem Pemantauan}

Sistem pemantauan dinamika laut dan atmosfer yang pernah dirancang sebagai bagian dari fasilitas NSTP-M PPU telah dapat direalisasikan pada TA 2015 dan beroperasi selama TA 2016. Sistem ini terpasang di Kantor PT. Angkutan Sungai, Danau dan Penyeberangan Indonesia Ferry (PT.ASDP Indonesia Ferry) cabang Penajam. Sistem ini merupakan rekayasa yang diterapkan dengan memanfaatkan teknik akusisi data melalui Sistem Near Real-Time ( $n R T)$ untuk pemantauan (monitoring) kondisi meteorologi dan oseanografi perairan yang berbasis komputerisasi dengan Single Board Computing (SBC). Sedangkan transmisi data menggunakan paket data dengan teknologi Global System for Mobile Communications (GSM) untuk akuisisi, yang telah dikembangkan sebagai Sistem Kontrol Otonom (Autonomous Control System). Sistem kontrol otonom untuk stasiun pemantaun maritim NSTP-M ini telah dipublikasikan secara terpisah oleh Nugroho et.al (2018). Pengembangan ini merupakan langkah awal dalam upaya membuat suatu sistem monitoring berbasis MeteorologyOceanography (Met-Ocean) Survey yang terintegrasi dengan sistem pendistribusian data dan informasi kelautan yang near real-time dan dapat diterima secara langsung di stasiun penerima data yang jaraknya jauh dari stasiun pengamatan. Edwing (2019) melaporkan suatu acuan ideal sistem ini yaitu pada Program PORTS milik NOAA (Gambar 2), yaitu suatu sistem sensor-sensor terintegrasi yang terkoordinasi di pelabuhan. Sistem ini memberikan akurasi dan informasi real-time yang andal tentang kondisi lingkungan. PORTS mengukur dan mendistribusikan hasil pengamatan untuk ketinggian air, arus, gelombang, celah udara, suhu air, salinitas, dan parameter meteorologi. PORTS dikembangkan dan diimplementasikan di awal 1990-an sebagai tanggapan atas kecelakaan di Teluk Tampa di mana sebuah kapal menabrak Jembatan Sunshine Skyway mengakibatkan hilangnya nyawa dan harta benda yang cukup besar. Program ini dibentuk sebagai kemitraan publik-swasta di mana masyarakat lokal mendanai 
pembangunan dan pemeliharaan dari sistem pengamatan lokal, dan NOAA menyediakan program dan manajemen data. Saat ini, PORTS telah berkembang ke lebih dari 30 lokasi di seluruh Amerika Serikat dan menunjukkan manfaat dalam mengurangi kecelakaan laut. Sistem pemantauan maritim di PPU ini mencoba untuk menyerupai sistem Program PORTS milik NOAA tersebut.

Konfigurasi sistem pemantauan lingkungan perairan yang dibangun sebagai prototipe sistem pengamatan maritim NSTP-M PPU adalah seperti yang digambarkan pada Gambar 3. Sistem ini diupayakan sebagai pendukung dalam program menghimpun data oseanografi perairan di Kawasan NSTP-M PPU di Kawasan Buluminung, Teluk Balikpapan, Kalimantan Timur. Prototipe sistem monitoring met-ocean yang berhasil terpasang dalam stasiun pengamatan maritim ini adalah dengan menggabungkan berbagai peralatan sebagai berikut:

a. Automated Weather Station (AWS) Tipe MetPak RG (+ Rain Gauge) merek Gill Instruments.

b. Side-Looking ADCP Argonaut Tipe SL-500 merek SONTEK.

c. Pendistribusi Data Tipe SPF-1500 Merk SONTEK dan Kabel catu daya sepanjang 200 meter.

d. Manajemen Kelistrikan (Power Management). Sistem pengatur catu daya listrik ini terdiri dari beberapa komponen antara lain: Pengatur Daya (Solar Panel dan Baterei Kering) dan Regulator (BCR Controller, PCB Power, Inverter, Panel display dan komponen proteksi tambahan, seperti kipas pendingin, saklar, Magnetic Circuit Breaker (MCB). Detail manajemen kelistrikan dapat dilihat pada Gambar 4.

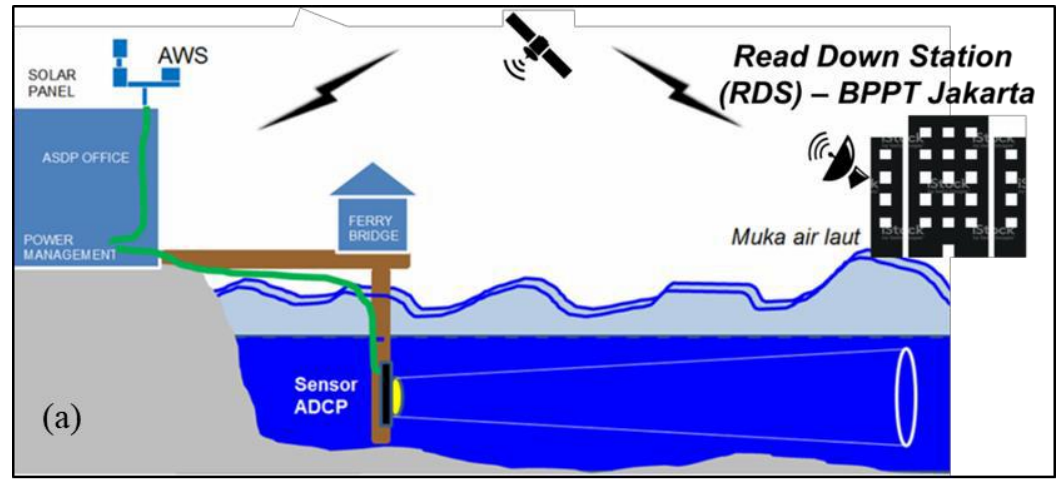

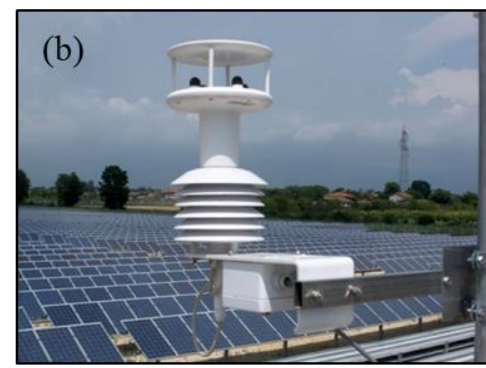

(AWS MetPak RG)

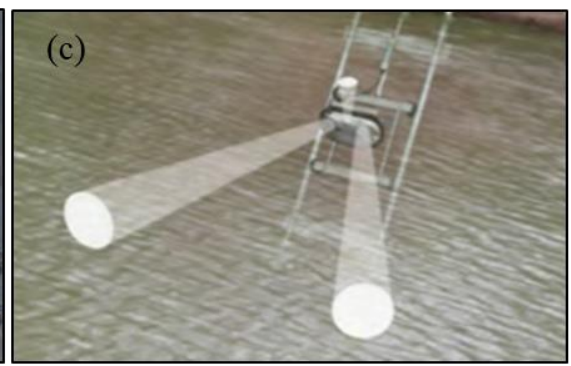

(ADCP Argonoaut SL-500)

Gambar 3. (a) Konfigurasi Stasiun Pengamatan Maritim NSTP-M, (b) sensor meteorologi AWS dan (c) sensor pengukuran arus permukaan dengan Side-Looking ADCP 


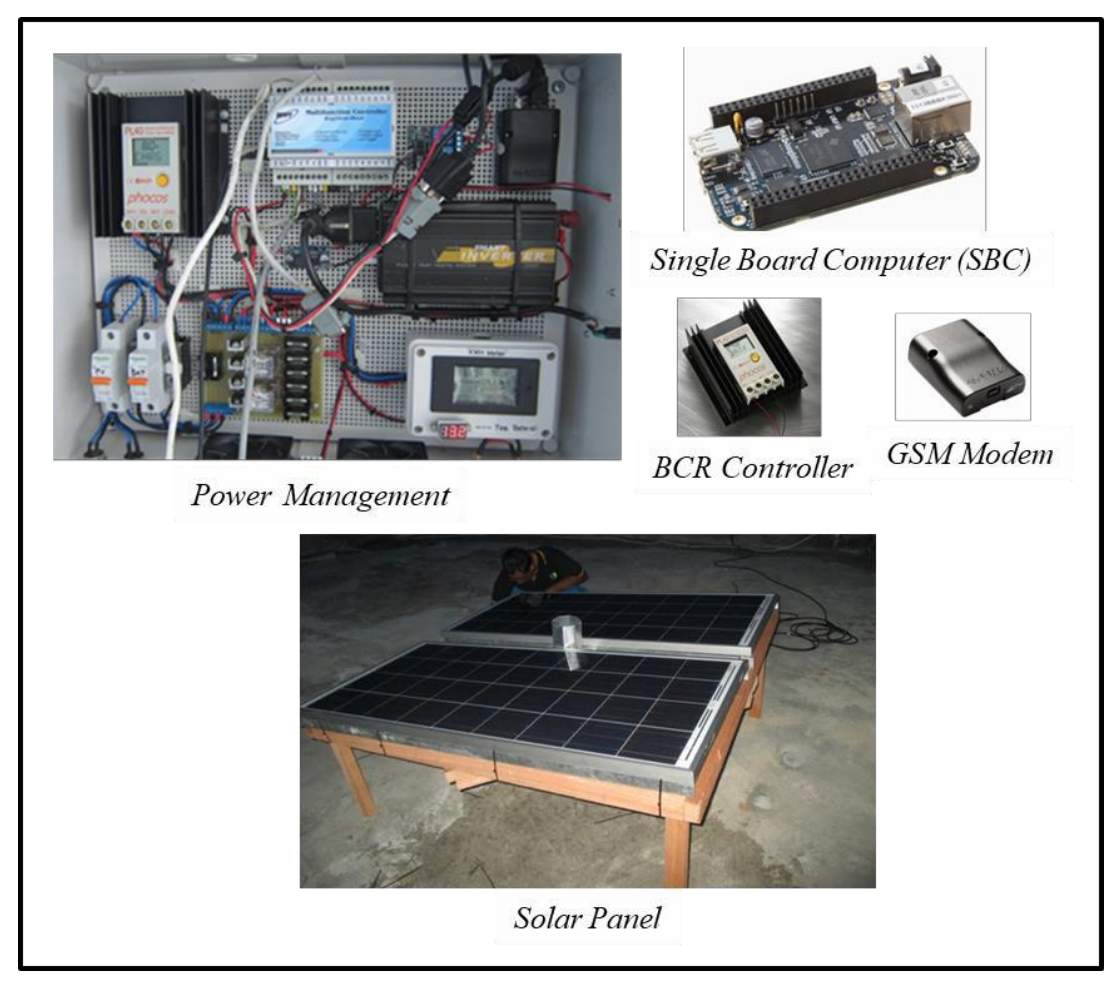

Gambar 4. Sistem Pengaturan Daya (Power Management) pada Stasiun Pengamatan NSTP-M PPU.

\section{Data Pengamatan}

Prototipe stasiun pengamatan maritim NSTP-M PPU mampu melakukan pemantauan parameter lingkungan perairan dan udara seperti, kecepatan dan arah angin permukaan, suhu udara permukaan, elevasi pasang surut, kecepatan dan arah arus permukaan (Gambar 5 dan 6). Seluruh data hasil pengukuran dari stasiun pengamatan maritim ini adalah dalam bentuk binary dan teks secara near real-time dapat dikirimkan secara kontinyu setiap jam ke Read-Down-Station (RDS) atau Pusat Penerima dan Pengelolaan Data yang bertempat di Gedung 1 BPPT Lantai 20, Jl. MH. Thamrin 8, Jakarta. Data-data yang terkirim ini selanjutnya dapat divisualisasikan dalam bentuk grafik dan gambar menurut parameter yang diukur (Gambar 5 dan 6). Selain menjadi bagian dari sistem pemantauan, data yang ditampilkan di RDS juga dapat diakses oleh berbagai pengguna untuk berbagai tujuan, baik untuk penelitian, pembuatan kebijakan maupun untuk keperluan lain melalui mekanisme perijinan. Sebagai contoh, Gambar 5 dan 6 menunjukkan tampilan data di RDS sebagai hasil pengukuran vektor kecepatan angin, suhu udara permukaan, pasang surut laut dan vektor arus laut permukaan pada periode bulan Agustus - November 2016.

Pada Gambar 5, hasil pengukuran arah dan kecepatan angin ditampilkan dalam bentuk vektor (kekuatan dan arah) dengan satuan pengukuran masing-masing dalam meter/detik $(\mathrm{m} / \mathrm{s})$ dan derajat azimuth $\left({ }^{\circ}\right)$. Pada bulan November 2016, arah angin didominasi dalam arah Tenggara dan Selatan, dengan kecepatan 6-8 m/det (lihat Gambar 7). Sementara pada pengukuran suhu udara permukaan diperoleh pola diurnal dengan nilai suhu maksimum dan minimum masing-masing sebesar $33,5{ }^{\circ} \mathrm{C}$ dan $22,5{ }^{\circ} \mathrm{C}$, dan dengan nilai rata-rata $28,0^{\circ} \mathrm{C}$. Stasiun AWS ini dipasang pada koordinat geografis $116^{\circ} 46^{\prime} 36.68$ "BT dan $1^{\circ} 14^{\prime} 38.58^{\prime \prime}$ LS pada ketinggian $~ 10$ meter diatas permukaan laut. 


\section{(- PDBI - METOCEAN \\ A Beranda 6 Peta 4 Buoy RAMA $O$ stasiun Aws $>$ Buoy Inatriton $O$ Data Oseanografi}

a) Arah Angin PENAJAM PASER UTARA

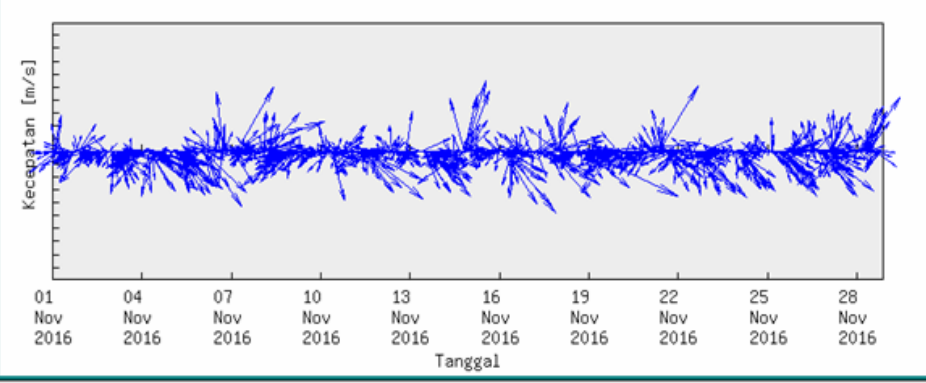

b)

Grafik Sulhu Udara PENAJAM PASER UTARA

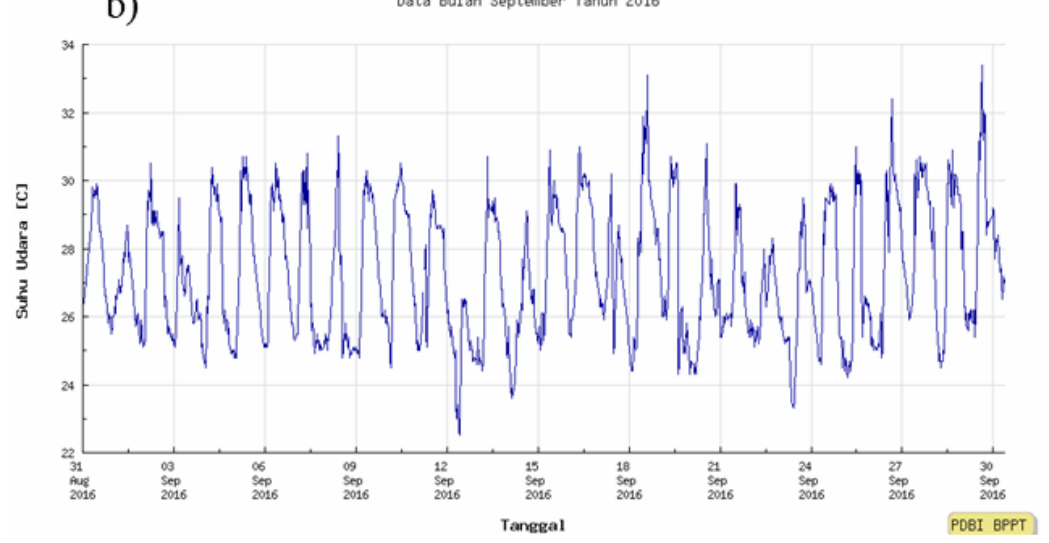

c)

Grafik Permukaan Air Laut PENAJAm PASER UTARa
Data Bulan Agustus Tahun 2016

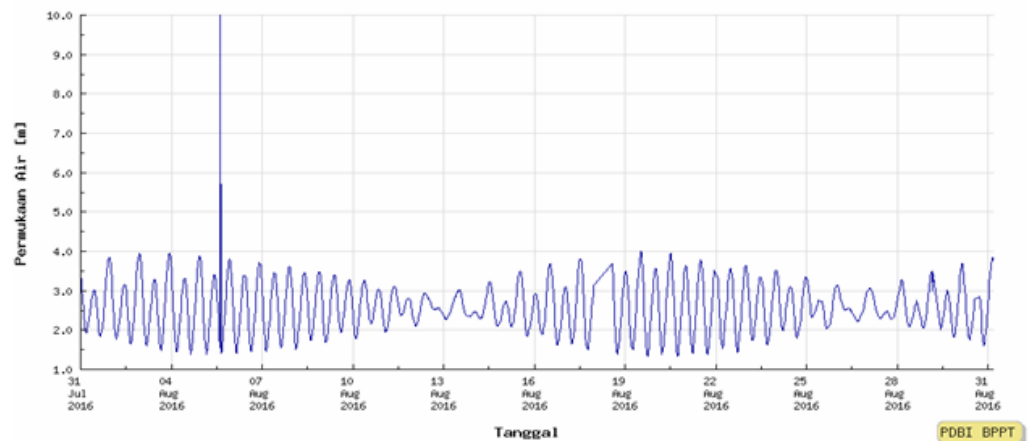

Gambar 5. Tampilan grafis vektor kecepatan angin dalam $\mathrm{m} / \mathrm{s}$ (a), suhu udara permukaan dalam ${ }^{\circ} C(\mathrm{~b})$, dan elevasi pasang surut laut dalam meter (c) pada hasil visualisasi pada data pengamatan di Stasiun Pengamatan NSTPM yang diterima di RDS. 


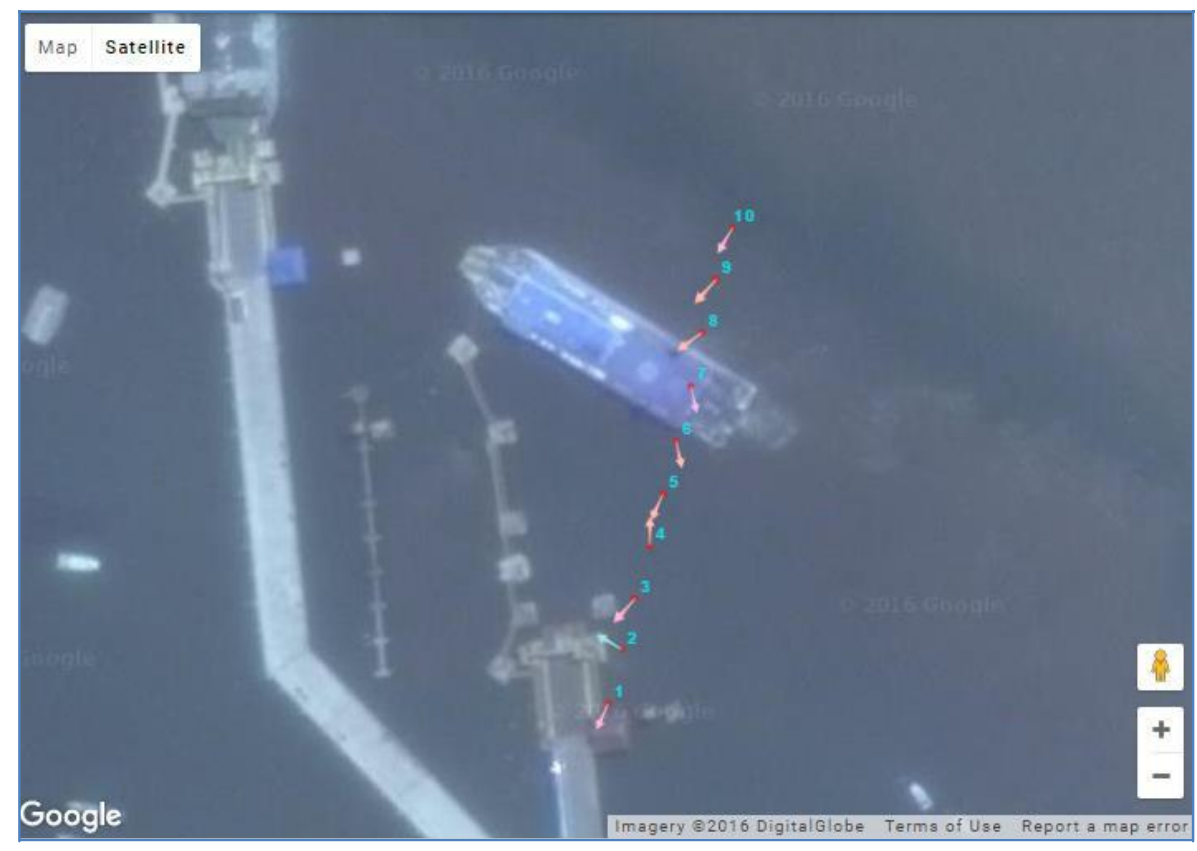

Gambar 6. Tampilan vektor arus laut permukaan hasil visualisasi pada data pengamatan di Stasiun Observasi NSTP-Maritim yang diterima di RDS.

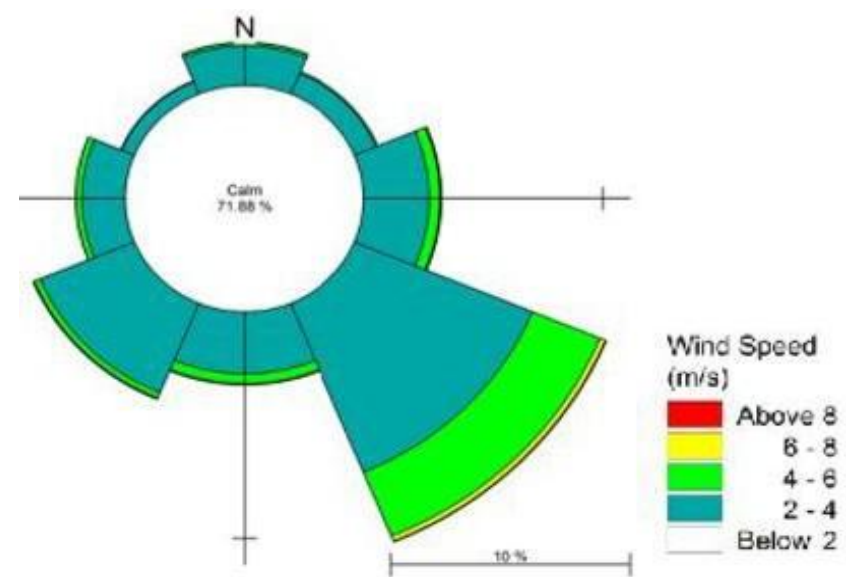

Gambar 7. Windrose kecepatan $(\mathrm{m} / \mathrm{sec})$ dan arah angin pada bulan November 2016 di Stasiun Pengamatan NSTP-M Kab. PPU.

Dari data pasang surut laut, diperoleh hasil perhitungan konstanta pasut (8 komponen) menggunakan metode least square dari data hasil pengamatan pasut pada periode waktu yang sama (Tabel 1). Stasiun pasang surut ini adalah sensor tekanan kolom air dari ADCP Argonout SL-500 (kedalaman sensor 3.5m dibawah dermaga) yang dipasang pada rumah kontrol penyeberangan ferry di PT. ASDP Indonesia Ferry Penajam pada koordinat geografis $116^{\circ} 46^{\prime} 36.94 " B T$ dan $1^{\circ} 14^{\prime} 30.42^{\prime \prime}$ LS.

Berdasarkan perhitungan bilangan Formzhal (F), diperoleh nilai $\mathrm{F}$ sebesar 0,37 yaitu tipe campuran cenderung harian ganda (mixed mainly semidiurnal tides); terjadi dua kali pasang dan dua kali surut dalam satu hari, dan terkadang terjadi satu kali pasang dan satu kali surut dengan tinggi dan waktu kejadian yang berbeda-beda. Hasil ini mirip seperti studi pengamatan langsung di lapangan yang dilakukan oleh Soeyanto 
dan Arifiyana (2018) dan Witono et al. (2013). Hasil ini menunjukkan bahwa sistem pengukuran near real time yang dipantau melalui stasiun pengamatan maritim NSTP-M PPU dan diterima oleh RDS di Jakarta berfungsi dengan baik dan menghasilkan kualitas data yang dapat diterima. Meskipun demikian, dalam pengukuran pasang surut tetap diperoleh noise-noise dan gap data, tetapi hal ini bukan merupakan kendala yang serius.

Tabel 1. Hasil analisis harmonik pasang surut di Pelabuhan Ferry PT.ASDP, PPU.

\begin{tabular}{|c|c|c|c|c|c|c|c|c|c|}
\hline Tide component & Zo & Q1 & O1 & P1 & K1 & N2 & M2 & S2 & K2 \\
\hline Amplitude (cm) & 271 & 3.7 & 15.6 & 7.9 & 24.5 & 7.1 & 67.1 & 40.9 & 11.4 \\
\hline Phase $\left({ }^{\circ}\right)$ & & 99.3 & 203.5 & 290.5 & 272.1 & 359.6 & 101 & 217.4 & 20.3 \\
\hline
\end{tabular}

Pengukuran arus permukaan pada kedalaman 0-1.5 m dilakukan pada 10 titik dengan jarak sejauh 120 meter dari sensor ADCP terpasang. Gambar 6 menunjukkan visulalisasi vektor-vektor arus permukaan yang menunjukkan pola arus pada suatu waktu tertentu (snapshot). Hasil pengukuran ini dapat digunakan lebih lanjut untuk menganalisa dan memprediksi pola arus di perairan tersebut.

\section{KESIMPULAN}

Prototipe Stasiun Pengamatan Maritim telah dapat dikembangkan untuk dalam rangka melengkapi pembangunan NSTP-M di Kab. Penajam Paser Utara, Kalimantan Timur. Stasiun pengamatan tersebut mampu melakukan pemantauan parameter lingkungan perairan dan udara secara near real-time (nRT) yang terintegrasi dalam proses pengelolaan dan pengolahan data nya pada pusat kendali dan penerima data di RDS yang berlokasi di Gedung BPPT, Jakarta. Data yang diperoleh memenuhi kualitas berdasarkan perbandingan yang telah dilakukan dengan hasil pengamatan lapangan. Parameter lingkungan yang diukur antara lain kecepatan dan arah angin permukaan, suhu udara permukaan, pasang surut laut, kecepatan dan arah arus permukaan.Kedepannya diharapkan dapat dilakukan penyempurnaan-penyempurnaan khususnya dalam proses pengolahan data yaitu tidak hanya mengumpulkan raw data dan mengirimkan ke pusat kontrol di Gedung BPPT tetapi diperlukan proses-proses filtering terhadap noise dan data filling pada gap data sebelum ditampilkan ke publik.

\section{UCAPAN TERIMA KASIH}

Ucapan terima kasih kepada Direktur Pusat Teknologi Pengembangan Sumberdaya Wilayah (PTPSW)-BPPT dan Kepala Balai Teknologi Survei Kelautan (BTSK)-BPPT, Dinas Perhubungan, Kebudayaan dan Pariwisata Kab. Penajam Paser Utara dan PT. Angkutan Sungai, Danau dan Penyeberangan Indonesia Ferry (PT.ASDP Indonesia Ferry) Penajam yang telah memberikan kesempatan, akses dalam Survei Pemetaan Untuk Calon Lokasi Kawasan National Science Technopark (NTSP) Maritim tahun 2015-2016. Ucapan terima kasih juga kepada segenap Tim Survei BTSK dan PTPSW yang berperan penting dalam melakukan koordinasi dengan instansi terkait, akuisisi dan analisis data sehingga artikel ini dapat disusun. 


\section{DAFTAR PUSTAKA}

Ardhyastuti, S. (2019). Pola dan Sebaran Sedimen Wilayah Perairan Buluminung, Penajam Paser Utara. Jurnal Rekayasa Lingkungan, 12(1), 1-14.

Balai Teksurla. 2016. Pembangunan Pusat Riset dan Inovasi Teknologi Kelautan. Laporan Akhir (Program Document). Balai Teknologi Survei Kelautan, Badan Pengkajian dan Penerapan Teknologi. Jakarta. p. 273.

Edwing, R.F. (2019). NOAA's Physical Oceanographic Real Time System (PORTS®). Journal of Operational Oceanography. 12(sup2), S176-S186. DOI: 10.1080/1755876X.2018.1545558.

KKP. (2018). Potensi Usaha dan Peluang Investasi Kelautan dan Perikanan Provinsi Kalimantan Timur. Dirjen Penguatan Daya Saing Produk Kelautan dan Perikanan, Kementerian Kelautan dan Perikanan (KKP). p. 136.

Nugroho, R.A., Andrianshah, P., Fauzi, A., Wiguna, T. (2018). Autonomous Controller for MetOcean Monitoring Station. In: Proceeding of the 2018 International Seminar on Application for Technology of Information and Communication (iSemantic), Semarang, Indonesia, 21-22 September 2018. P. 71-76. DOI: 10.1109/ISEMANTIC.2018.8549743.

Soeyanto, E., dan Arifiyana. (2018). Dinamika proses sedimentasi di perairan muara Sungai Riko, Teluk Balikpapan. Oseanologi dan Limnologi di Indonesia 3(1), 6372.

Soeyanto, E. (1998). Aplikasi Bahasa Pemrograman MATLAB dalam Analisa Harmonik dan Visualisasi Arus Pasang Surut. Dalam: Teknologi Survei Laut Seri 2, (hal 55-70), UPT Baruna Jaya BPPT, ISBN: 979-95038-7-6

Simreg-Bappenas. (2015). Seri Analisis Pembangunan Wilayah Provinsi Kalimantan Timur 2015. Sistem Informasi dan Managemen Data Dasar Regional (Simreg)Badan Perencanaan Pembangunan Nasional (Bappenas). p. 40 (Akses Maret 2020 melalui https://simreg.bappenas.go.id)

Witono, A., Nugroho, D., Widada, S., dan Novico, F. (2013). Pemodelan Pola Arus Pada Perairan Teluk Balikpapan Dengan Menggunakan Software Mike21. Jurnal Oseanografi, 2(3), 337-345.

Wahyono, H.D. (2018). Penerapan Teknologi Online Monitoring Kualitas Air di Indonesia. Dalam: Prosiding Seminar Nasional dan Konsultasi Teknologi Lingkungan Jakarta, 20 September 2018. pp. 42-51.

. (2009). Argonaut-SL System Manual Firmware Version 12.0, Sontek/YSI, Inc., San Diego, CA 92121-3091, USA . (2016). MetPakRG Weather Station Use Manual (Firmware version 24364.01.01), Gill Instrument Limited, Hampshire,SO419EG,UK 